\title{
Professor David Pearce (1941-2005)
}

\author{
EKIN BIROL, PHOEBE KOUNDOURI, and DAVID MADDISON
}

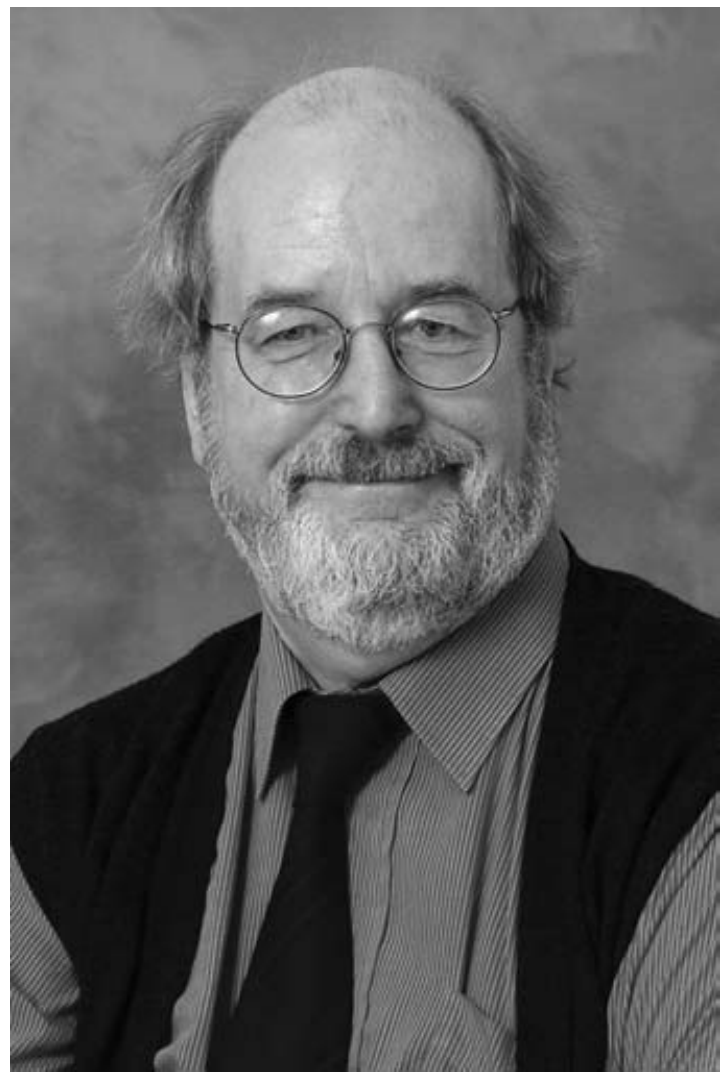

David Pearce was one of the founding fathers of the discipline of environmental economics. His ideas have had a tremendous impact on the conduct of environmental policy in Europe and beyond. To his students and those he sought to influence, he was a persuasive purveyor of new ideas, the original 'Green Guru'.

David was born on the 11 October 1941. He went to Lincoln College Oxford where he was awarded a first in politics, philosophy, and economics in 1963. His first academic position was as lecturer in economics at Lancaster. He then went on to hold academic positions in Southampton as senior lecturer, in Leicester where he was director of the Public Sector Economics 
Research Centre, and in Aberdeen where he was appointed professor of political economy. In 1983 he joined University College London (UCL), quickly becoming head of the Economics Department. In 1990 he founded the M.Sc. course in environmental and natural resource economics at UCL and in 1991 he established the ESRC funded Centre for the Social and Economic Research on the Global Environment (CSERGE) at UCL and the University of East Anglia.

Perhaps David's most influential piece of work was his best-selling book, Blueprint for a Green Economy (with Anil Markandya and Ed Barbier), published in 1989, and considered a 'political event of the first importance'. Better known as the Pearce Report, it recommended that environmental impacts should be brought to formal policy appraisal wherever possible. More explicitly, the report stated that: 'A government's policies can affect the environment from street corner to stratosphere. Yet environmental costs and benefits have not been integrated into government policy assessment, and sometimes they have been completely forgotten entirely. Proper consideration of these affects will improve the quality of policy making.' The Pearce Report was a succinct and compelling statement of how economics could and should inform environmental policy making.

David argued that sustainable development did not mean that economic activity should never deplete or degrade the environment, rather he defined the minimum conditions for such depletion and degradation to be acceptable. David further believed that, in order to integrate environment into policy making, the value of the environment should be measured in monetary terms and included in a cost-benefit analysis of any policy that impacts on the environment. David was a leading advocate of the use of market-based instruments, such as pollution taxes, tradeable permits, and compensation for conservation. He implemented his ideas in the policy arena through his work with the UK government, the OECD, the World Bank, the UN, and European Commission.

David was the author and editor of over 300 papers and 50 books. His achievements were widely recognized during his lifetime. In 1989 the UN included him in the 'Global 500' roll of honour, and in 2000 the Queen awarded him with an OBE. In July of this year the European Association of Environmental and Resource Economists presented him with a lifetime achievement award, and honoured him with a standing ovation.

As an individual he was unusually generous with his time. Even after returning exhausted to his office after one of his many trips he would still find time to speak to the queue of students waiting outside his office. Irrespective of their academic abilities, they were always treated with courtesy and respect. David was very supportive of junior members of staff. He propelled people along career paths that without his encouragement they would never even have contemplated.

David passed away unexpectedly of leukaemia on the 8 September 2005. As an academic - through a combination of his intellectual gifts, hard work, and personal charm - he managed to achieve enormous success. He was someone of great wisdom and vision, someone who left an indelible stamp on the entire planet. 